\title{
Analysis on The Problems Existing in The Financing of Private Enterprises in China and The Relationship Between Private Financing
}

\author{
Dongdong Weng \\ Quanzhou Normal University \\ Quanzhou, China
}

\author{
Xiaofang Wang* \\ Liming Vocational University archives \\ Quanzhou, China \\ weng28911985@163.com
}

\author{
Manping Weng \\ College of International Trade \\ Liming Vocational University \\ Quanzhou, China \\ weng28911985@163.com
}

\begin{abstract}
With the continuous advancement of marketization level, private enterprises play a vital role in economic operation, but their financial resources are asymmetric with their status in national economic and social development. The development of enterprises is generally a problem of financing difficulties. This paper analyzes the reasons for the difficulty of financing private enterprises in China from three aspects: the enterprise itself, the bank and the government. It analyzes that private financing brings certain risks to the development of private enterprises, and analyzes the status quo of the integrity of private enterprises in China.
\end{abstract}

\section{Keywords-Financing; Integrity level ; Private enterprise}

\section{REASONS FOR DifFICULTIES IN FINANCING PRIVATE ENTERPRISES}

\section{A. Enterprise's Own Reasons}

Compared with state-owned large-scale enterprises, private enterprises appear to be smaller in scale, with lower production technology levels, relatively simple product structures, weak information concepts, and unacceptable fluctuations in the prices of raw materials and the industries in the market. Therefore, private enterprises existed. Big business risks. Compared with large-scale enterprises, private enterprises only have relatively insufficient funds, and they often have behaviors that are arrears to bank loans and interest resulting in low creditworthiness. Privately-owned enterprises are less regulated in financial matters, and there is a situation in which certain financial information is deliberately concealed from being disclosed. Banks and other financial institutions have raised the threshold of financing for private enterprises because of their distrust in their financial and other information. This has also increased private enterprises. Financing difficulty. [1]

\section{Foundation Project:}

1.Fujian Provincial Education Science "Thirteenth Five-Year Plan" 2017 Cross-Strait Vocational Education Special Research Project(FJJKHX17-077). 2..2018 Fujian Province Young and Middle-aged Teacher Education Research Project "I Offer Good Strategies for Building New Fujian" (United Front Work Project) (Key Funding Project) (JZ180019).

3.Quanzhou Normal University Student Innovation and Entrepreneurship Training Program Project Funding (Project No.: 201810399120).

\section{B. Bank Reasons}

First of all, the imbalance of system system policies directly affects bank loans and direct financing channels. The loans of the four major state-owned banks are mainly stateowned large enterprises. At the same time, as the country implements accountability for the balance of non-performing loans and overdue loans of banks, banks will be more cautious in choosing the target of loans, and private companies will have poor anti-risk capabilities and will often find it difficult to be the preferred target for bank loans. This has also affected the financing of private enterprises. Second, information asymmetry affects the relationship between banks and companies. Banks only provide loans, but do not participate in the business management of the company. Therefore, the flow of loan funds cannot be well monitored. Therefore, the asymmetric operation of information between banks and users of funds is used, and information disclosure by companies with funds (private enterprises) is not timely. This has created more contradictions and problems. Private enterprises have far-reaching differences in financial, operational and other information transparency, guarantee capabilities, and mortgage lending capabilities compared to large enterprises or state-owned enterprises. At the same time, due to the limitation of bank loans, banks are considering the financing risks, and banks are financing private enterprises. less. Finally, due to the lack of matching small and medium-sized financial institutions, the support for private enterprises' financing needs is low. [2]

\section{Reasons for Government Agencies}

The government has insufficient support for financing private enterprises and there is no long-term support policy. For a long time, the state's policies have often been tilted toward large enterprises or state-owned enterprises, and some preferential policies have been introduced. For ordinary private enterprises, these preferential policies are basically not 
available. As for the state's preferential tax policies, private enterprises are small-scale taxpayers, and the preferential policies that should be enjoyed often cannot be achieved in the end.

From the above analysis, it is known that strengthening cooperation between banks, governments and enterprises is one of the important ways to solve the problem of financing difficulties for private enterprises. By creating a diversified financing environment and establishing a sound credit rating system, the government has set up a The government-led, honest and trustworthy SME financing platform effectively solves the financing difficulties of private enterprises. [3]

\section{STATUS OF THE LEVEL OF INTEGRITY OF PRIVATE ENTERPRISES}

\section{A. Insufficient Financing Integrity}

Some private enterprises do not pay attention to their own credit, making banks reluctant to lend to this type of enterprise. According to statistical surveys conducted by authoritative organizations, $23.5 \%$ of these private enterprises that do not receive loans are due to the fact that these private enterprises have not paid interest on banks and have debt evasion and debts. They do not talk about honesty, which greatly affects financial institutions' loan support. The enthusiasm of private enterprise development. [4]

\section{B. The Lack of Business Integrity}

The words must be done, the line must be fruitful" is the ethical principle that both parties to the transaction must abide by when signing the contract. But behind the promotion of honest trading, there are still many acts of malicious default. Due to the lack of business integrity, it is difficult for private companies to obtain financing from some financial institutions.

\section{C. lack of Production Integrity}

Loss of production integrity mainly refers to hidden facts, fraudulent consumers, and pursuit of profits. Some private enterprises rely on the asymmetry of information between consumers and consumers, and do not strictly control the quality of product production. There is no strict quality system certification. In order to greatly reduce costs, use some inferior and harmful raw materials for production. For these consumers is not known, this is not only damage the interests of consumers, but also affects the credibility of enterprises, making consumers lower credit for enterprises, seriously restricting the development of private enterprises. [5]

\section{The Lack of Financial Integrity}

Some private companies provide false financial statements. In order to avoid taxation, some private companies even have several sets of statements, and even more excessive private companies collaborate with audit companies to create and falsify financial statement data, resulting in less tax or even less Pay taxes.
The lack of integrity of some private enterprises has seriously hampered the establishment of a creditworthy economy, which has resulted in the destruction of the market credit environment. Banks have become suspicious of the credit of private enterprises. This has jeopardized the private enterprises that want to raise funds through banks and has seriously affected the overall economic construction. On the other hand, the lack of integrity of some private enterprises is also a serious crisis to the healthy and orderly development of private enterprises. Consumers and investment strategies that lose confidence in the market will inevitably affect the development and growth of private enterprises. [6]

\section{PRIVAte FinAnCe AND PRIVAte EnterPrises}

\section{A. The Important Role of Private Financing in The Development of Private Enterprises}

1) The existence of private financing makes up for the gap in supply and demand of social funds: For a long time, the main channel for financing private enterprises was bank loans. However, as financial institutions strictly guard against credit risk, and generally implement strict credit authorization and authorization management, as well as the recovery of loan approval power from grass-roots financial institutions, the loan threshold is even higher. Therefore, it is more difficult for private enterprises to obtain bank loans. In order to maintain its survival and development, enterprises urgently need to inject funds to find the source of funds as a key issue. Under this background, the emergence of private financing has solved the problem of financing difficulties for private enterprises.

2) Non-government financing Solving problems caused by macro-control policies, such as financing difficulties, difficult loans, complicated procedures, and long periods for private enterprises: Up to now, quite a few private enterprises have rarely received credit support from banks, so private financing has become an important financing channel for private enterprises. [7]

3) Private financing solves the narrow investment channels of the public: At present, idle capital in the hands of urban residents continues to increase, formal investment channels are very limited, and investment profits are not high. Therefore, private lending, as a channel for many residents to transfer funds, seeks to achieve capital appreciation. It also solves the problem of funding sources for some SMEs.

4) Make up for credit services that formal financial institutions cannot provide: With the deepening of reform and opening up and the development of market economy, the scale of private enterprises has been continuously expanding, and the demand for financial services by private enterprises has been increasing. However, formal financial institutions cannot meet the needs of private enterprises in many areas and fields, and therefore those considered to be It is more and more accepted by people for informal financial private lending activities, and it has greatly promoted the development of private enterprises, but also because its loan procedures are 
simple and rapid, the loan term is flexible, and the loan amount is not subject to strict control advantages. The irreplaceable role of formal financial institutions. [8]

\section{B. Problems Brought by Private Financing to the Development of Private Enterprises}

Private capital (private capital) belongs to informal finance and has its own inherent defects. For example, it has scattered, concealed, disorderly operation of loan transactions, which may easily lead to redemption risks and other criminal activities, disrupting financial and economic order, and so on. At the same time, due to the unconstrained private capital, lack of correct guidance and supervision, randomness, random awareness, and not paying attention to long-term interests, not paying attention to social benefits and investment review, to some extent, weakening the government's macro The influence of policies interferes with the normal business activities of financial institutions and affects the development of normal industries. [9] It also increases the probability of financial risks, increases regional instability, and easily induces various economic cases and civil disputes, affecting regional stability. The potential risks of private enterprises should not be overlooked.

The four major state-owned banks are still in a monopoly position, accounting for almost three-quarters of deposits and loans, and their private financial institutions are lagging behind. Their development scales are uneven and their support for SMEs is insufficient. This has seriously affected SME financing needs. [10] Private companies have a huge funding gap, and they urgently need funds to turn around. Under this situation, more private financial institutions have been fostered. However, with the continuous development of the market, these private financial institutions have deviated from their original purpose. For example, the purpose of the Minsheng Bank building was to serve private enterprises and
SMEs. Later, it gradually evolved into a general commercial bank. There are also some financial institutions that have just started to serve private enterprises, but they are subject to the size of funds, service levels, etc. With regard to the restrictions, it also gradually controls the loans of private enterprises and raises the corporate finance threshold, which limits the financing of private enterprises. Therefore, to a certain extent, private financing is not enough to support the development of private enterprises.

\section{REFERENCES}

1] W.L. Liang, "On the Causes and Countermeasures of the Financing Difficulties of Private SMEs," Business research, vol. 11, pp. 61-64, 2001

[2] J.S. Chen, "Several Problems of "Financing Difficulty" of Private Enterprises," Economic System Reform, vol. 01, pp. 31-34, 2002.

[3] L. Xu and X. Xu, "Financing dilemma and countermeasures for nonstate-owned economic development," Soft Science, vol. 02, pp. 12-14, 2003

[4] Y.F. Lin and Y.J. Li, "Rethinking the development prospects of the second board market in China," Reform, vol. 02 , pp. 95-97, 2002.

[5] T. He, "Underground Economy" and Regulation Efficiency: An Empirical Study on the Legality of Folk Credit," Financial Research, vol 11, pp. 71-75, 2002

[6] G. Fan, "How to solve financial problems?" Reform, vol. 01, pp. 60-62, 2002.

[7] G. Wang, "Reflections on Several Issues Concerning the Construction of Credit Guarantee System for Small and Medium-sized Enterprises," Journal of Henan Financial Management Cadre College, vol. 05, pp. 4143, 2003.

[8] Y.H. Xu, "SME Development and Credit Guarantee System," Zhejiang Finance, vol. 08, pp. 55-58, 2002.

[9] H. Zhao and S.X. Liang, "Research on the Financing Problems of SMEs in the County in Economically Less Developed Areas: An Empirica Study Based on Survey Data of Henan Province Financial Theory and Practice," vol. 04, pp. 75-77, 2012.

[10] L.J. Jiang, "Solution to the Financing Difficulties of SMEs," Enterprise Reform and Management, vol. 2, pp. 25-28, 2011. 